\title{
Research on Relationship between "Direct Investment + Sponsor" Mode and IPO Pricing Efficiency
}

\author{
Yuanzhi Chen, Qixin Wang \\ School of Business Administration, South China University of Technology, Guangzhou, China \\ Email: qx_wang2012@126.com
}

How to cite this paper: Chen, Y.Z. and Wang, Q.X. (2018) Research on Relationship between "Direct Investment + Sponsor" Mode and IPO Pricing Efficiency. Modern Economy, 9, 263-277. https://doi.org/10.4236/me.2018.92017

Received: January 9, 2018

Accepted: February 8, 2018

Published: February 11, 2018

Copyright (c) 2018 by authors and Scientific Research Publishing Inc. This work is licensed under the Creative Commons Attribution International License (CC BY 4.0).

http://creativecommons.org/licenses/by/4.0/

\section{c) (i) Open Access}

\begin{abstract}
The paper takes 996 IPO companies in China from 2012 to 2016 as samples and investigates the effect on IPO pricing efficiency under the "Direct Investment + Sponsor" Mode. The research shows that there is no significant difference between companies that intend to IPO under the "Direct Investment + Sponsor" mode and companies that intend to IPO under the non-"Direct Investment + Sponsor" mode in the discount of new stocks and one-year returns. The result shows that the firewall mechanism between the direct investment department and the investment banking department of Chinese securities traders is in good condition, verifies the rationality of not abolishing "Direct Investment + Sponsor" mode in Guidelines for Direct Investment Business of Securities Companies introduced by China Securities Regulatory Commission in July 2011 and powerfully refutes the market's long-lasting query that China Securities Regulatory Commission retains "Direct Investment + Sponsor" mode. Meanwhile, it provides evidence for the existence compliance of "Direct Investment + Sponsor" mode with financial innovation made by securities traders on the occasion of introducing new policies such as Management Standards for Private Equity Subsidiaries of Securities Companies and Management Standard for Alternative Investment Subsidiaries ot Securities Companies.
\end{abstract}

\section{Keywords}

Direct Investment + Sponsor Mode, IPO Pricing Efficiency, Interest Conflict

\section{Introduction}

"Direct Investment + Sponsor" means that a securities trader that sponsors a pre-IPO company for listing purchases shares of the company before the signing 
of relative agreement or carrying out substantive business through its direct investment department. Since CITIC Securities, CICC and other securities traders first received the direct investment pilot licenses in 2007, direct equity investments made by securities traders in non-listed companies have been fully released. Till October 2010, there have been three batches including 29 securities companies that gain the pilot direct investment business qualifications.

For that, securities traders often buy stocks at low prices and they can also make huge profits by selling stocks at high prices after listing of companies or as coming of the limited sale period. However, the vast majority of securities traders conduct "Direct Investment + Sponsor" businesses mostly in the form of "purchasing stocks by surprise". Under the trend of maximizing profits, securities traders may relax their standards so as to help companies to be listed raise their issuing prices. In this case, companies to be listed may appear "performance change" phenomenon after the listing, which harms the interests of investors. "Purchasing stocks by surprise" and "bundled listing" almost become the pronoun for direct investment of securities traders. Therefore, "Sponsor + Direct Investment" mode has been deeply questioned by the market.

In July 2011, China Securities Regulatory Commission introduced Regulatory Guidelines for Direct Investment Business of Securities Companies (hereinafter referred as Guidelines for Direct Investment), which clearly stipulated that for securities trader investment banks that act as the counseling institution, financial advisor, sponsor institution or lead underwriter of companies to be listed, the direct investment subsidiaries, direct investment funds, industrial funds and fund management agencies of securities trader that investment banks belong to may no longer invest companies to be listed since the signing of relative agreement or carrying out substantive business. It means the end of doubtful "Sponsor + Direct Investment" business since 2007 but the "Direct Investment + Sponsor" business mode continues to last (Table 1).

Although China Securities Regulatory Commission halted the "Sponsor + Direct Investment" mode in July 2011, it still allowed the existence of "Direct Investment + Sponsor" mode. According to the data manually collected by the author, 73 of 996 pre-IPO companies from 2012 to the end of 2016 have the phenomenon of "Direct Investment + Sponsor" and there has always been controversy in theory and practice.

In December 2016, China Securities Regulatory Commission introduced Management Standards for Private Equity Subsidiaries of Securities Companies and Management Standard for Alternative Investment Subsidiaries of Securities Companies again, which regularized the "Direct Investment + Sponsor" mode again and also meant that "Direct Investment + Sponsor" mode became the public focus once again. On the historical node, this article studies whether the "Direct Investment + Sponsor" mode brings the benefit transfer problem in the past five years so as to provide theoretical reference for further regulation and development of investment banking business in China. 
Table 1. List for relevant laws and regulations about "Sponsor + Direct Investment" or "Direct Investment + Sponsor" business.

\begin{tabular}{|c|c|c|}
\hline Time & $\begin{array}{l}\text { Laws and } \\
\text { regulations and } \\
\text { departments }\end{array}$ & Contents \\
\hline $\begin{array}{c}\text { December, } \\
2008\end{array}$ & $\begin{array}{c}\text { China Securities } \\
\text { Regulatory } \\
\text { Commission issued } \\
\text { Management Measures } \\
\text { for Securities Issuance, } \\
\text { Listing and } \\
\text { Sponsor Business }\end{array}$ & $\begin{array}{l}\text { If the sponsor institution and its controlling } \\
\text { shareholder, actual controller and important related } \\
\text { parties held more than } 7 \% \text { total shares of the issuer or } \\
\text { the issuer held or controlled more than } 7 \% \text { shares of } \\
\text { the sponsor institution, the sponsor shall unite a } \\
\text { non-associated sponsor agency to perform sponsor } \\
\text { duties together as issuing and listing securities of the } \\
\text { issuer and this non-associated sponsor } \\
\text { institution was the first sponsor institution. }\end{array}$ \\
\hline 2009 & $\begin{array}{c}\text { China Securities } \\
\text { Regulatory } \\
\text { Commission } \\
\text { introduced Guidelines } \\
\text { for Direct Investment } \\
\text { Business Pilot of } \\
\text { Securities Companies }\end{array}$ & $\begin{array}{l}\text { It clearly put forward that securities companies } \\
\text { carried out direct investment business in the form of } \\
\text { subsidiaries, which achieved more stringent institu- } \\
\text { tional separation than internationally } \\
\text { accepted behaviors of establishing direct } \\
\text { investment departments within the securities compa- } \\
\text { nies; it stipulated that net capital of pilot securities } \\
\text { companies in recent } 12 \text { months } \\
\text { should not be less than } 1.5 \text { billion; securities } \\
\text { companies invested direct investment subsidiaries } \\
\text { with their own funds and the amount should not ex- } \\
\text { ceed } 15 \% \text { net capital of securities companies. }\end{array}$ \\
\hline July, 2011 & $\begin{array}{l}\text { China Securities } \\
\text { Regulatory } \\
\text { Commission } \\
\text { introduced Guidelines } \\
\text { on Supervision for } \\
\text { Direct Investment } \\
\text { Business of } \\
\text { Securities } \\
\text { Companies }\end{array}$ & $\begin{array}{l}\text { It clearly stipulated that for the counseling institution, } \\
\text { financial advisor, sponsor institution or lead } \\
\text { underwriter for companies to be listed, their direct } \\
\text { investment subsidiaries, direct investment funds, } \\
\text { industrial funds and fund management agencies may } \\
\text { no longer invest companies to be listed } \\
\text { since the signing of relative agreement } \\
\text { or carrying out substantive business. }\end{array}$ \\
\hline $\begin{array}{c}\text { December, } \\
2016\end{array}$ & $\begin{array}{l}\text { The Securities } \\
\text { Association of China } \\
\text { introduced } \\
\text { Management Standards } \\
\text { for Private Equity } \\
\text { Subsidiaries of } \\
\text { Securities Companies, } \\
\text { Management Standard } \\
\text { for Alternative } \\
\text { Investment } \\
\text { Subsidiaries of } \\
\text { Securities Companies }\end{array}$ & $\begin{array}{l}\text { In the future, securities traders could only set up one } \\
\text { wholly-owned fund subsidiary which must be solely } \\
\text { engaged in investment business and sub-subsidiaries } \\
\text { with comprehensive investment business were not } \\
\text { allowed to be established. The company must be a fund } \\
\text { management company with an exclusive business } \\
\text { boundary. Parent company should strengthen risk } \\
\text { controls and capital constraints of subsidiary company, } \\
\text { assume heavier regulatory responsibilities than before } \\
\text { and conduct a comprehensive review of risks. The } \\
\text { Securities Association of China would enhance the risk } \\
\text { management of direct investment made by securities } \\
\text { trader. In the future, monthly, quarterly and annual } \\
\text { reports needed to be uploaded regularly. }\end{array}$ \\
\hline
\end{tabular}

The research shows that there is no significant difference between companies that intend to IPO under the "Direct Investment + Sponsor" mode and companies that intend to IPO under the non-"Direct Investment + Sponsor" mode in 
the discount of new stocks and one-year returns. The result shows that the firewall mechanism between the direct investment department and the investment banking department of Chinese securities traders is in good condition, verifies the rationality of not abolishing "Direct Investment + Sponsor" mode in "Guidelines for Direct Investment Business of Securities Companies" introduced by China Securities Regulatory Commission in July 2011 and powerfully refutes the market's long-lasting query that China Securities Regulatory Commission retains "Direct Investment + Sponsor" mode. Meanwhile, it provides evidence for the existence compliance of "Direct Investment + Sponsor" mode with financial innovation made by securities traders on the occasion of introducing new policies such as Management Standards for Private Equity Subsidiaries of Securities Companies and Management Standard for Alternative Investment Subsidiaries of Securities Companies.

The structure of following parts is as follows: The second part is the theoretical analysis and research hypothesis, in which it mainly analyzes the effects of "Direct Investment + Sponsor" mode on the new share discount and long-term performance under two different hypotheses and then puts forward research hypotheses; the third part is the study design and it introduces the sample selection and empirical test methods; the fourth part is the empirical results and analysis; the last part is the conclusion and recommendations.

\section{Theoretical Analysis and Hypothesis}

Zhang Yichun and Hong Tu (2012) studied the interest conflict of IPO listed companies under the mode of "Direct Investment + Sponsor" and found that the "Direct Investment + Sponsor" mode did not significantly aggravate the interest conflict and it was indicated that the regulation of regulators in our country and the internal firewall system of securities companies effectively regulated the interest conflicts in the "Direct Investment + Sponsor" mode [1]. However, although the paper studies and concludes whether there is the interest conflict in the "Direct Investment + Sponsor" mode, the chosen samples are only IPO companies during the one-year period from October 21, 2009 to December 28, 2010 and before the introduction of Guidelines for Direct Investment in July 2011, in such relaxed regulatory environment the sample size was small and the representativeness was relatively weak. The author selects IPO companies under the Direct Investment + Sponsor mode after the release of Guidelines for Direct Investment in July 2011 as samples, selected samples not only become more adequate but also become more representative in a more regulated regulatory environment. In the view of time sequence, it even becomes more capable of examining the policy effect of Guidelines for Direct Investment in July 2011.

From mainly focusing on securities brokerage services to developing all the capital market business, securities companies are also faced with risks of internal business interest transfer in the business diversification. In essence, such risks stem from the information asymmetry in capital markets. Although regulators 
stipulate that enterprises should put prospectus in public with financial data in every three years at the time of listing so as to lower the information asymmetry in the IPO process, the sponsor securities traders still hold the information that is unknown to the outside world, which actually leads the information of companies to be listed to the information asymmetry among stakeholders. Such information asymmetry not only affects the accuracy of pricing, damages the interests of investors and even also results in the failure of securities issuance and hindering to achieve the resource allocation function of capital market.

Under the circumstance of information asymmetry, investors want to buy shares at lower prices and issuers want to issue shares at higher prices. Sponsor securities traders, originally as third parties, also shoulder the role of underwriting and have the incentive to promote the issuing price (the higher the issuing price, the greater the underwriting income). However, in the "Direct Investment + Sponsor" mode, securities traders have another role of "pre-IPO investors" and more hope to constantly rise the stock price before the limited sale period comes. Driven by the interests of dual identity, the interest transfer behaviors of securities traders may be more prominent.

One of typical cases for potential interest transfer in the "Direct Investment+ Sponsor" mode is Bros Eastern. As the "Direct Investment + Sponsor" project of CITIC Securities, Bros Eastern was listed on June 12, 2012. However, its performance dramatically dropped in the semi-annual report two months after the listing and its net profit in the first half of 2012 dropped as much as $72.05 \%$ on year-on-year basis. China Securities Regulatory Commission issued a letter of warning and other regulatory measures to the sponsor securities trader CITIC Securities.

The interest transfer in the "Direct Investment + Sponsor" mode is mainly reflected in the following: The underwriting teams of investment banks can directly affect the pricing process of IPO and the direct investment departments of securities traders can indirectly affect IPO pricing through the internal relationship with underwriting teams. Since the judging standards for "Direct Investment + Sponsor" or "Sponsor + Direct Investment" in Guidelines for Direct Investment are the time sequence based on behaviors, the time sequence of "first direct investment then sponsor" is the main method to prevent the internal direct investment departments of securities traders from transferring interests with investment banking departments. "The day when signing the relative agreement or carrying out substantive business", therefore becomes a paradoxical place for securities traders to carry out the "direct investment + sponsor" business and whether it can be "inside equals outside" mainly depends on whether the internal firewall of securities traders is valid.

If the internal firewall of securities traders is valid, its internal direct investment department and investment banking department can be effectively isolated. At this time, the investment banking department can hold an objective sponsor attitude and the sponsor work of investment banking department will 
not be affected by the interests of direct investment business so as to effectively avoid the situation of interest transfer. If the internal firewall of securities traders is invalid, the direct investment department of securities traders can indirectly affect the IPO pricing through the relationship with underwriting teams of investment banking department from the perspective of interest transfer. The impacts on the pricing process include two aspects (Kroszner and Rajan, 1994; Gompers and Lerner, 1998; Hamao and Ritter, 2000):

1) Rational discount hypothesis:

The rational discount hypothesis argues that investors are rational and they know this process of interest transfer and foresee the subsequent risks so that they require higher discounts to make up for possible future risks and losses brought by the interest transfer. From the first day performance of stocks in the stock market, it is mainly reflected as higher discounts, lower issuing prices and lower PE ratio [2]. However, from the long-term performance of stocks investors acquire more information and the PE ratio on the first day of issue is lower, so the long-term performance of stocks with interest transfer may be not too bad [3].

2) Ignorant investor hypothesis:

The ignorant investor hypothesis believes that investors are not rational and they cannot know this process of interest transfer in advance nor can foresee the future risks, so they will not require higher discounts to make up for possible future risks and losses brought by the interest transfer. From the first day performance of stocks in the stock market, its discount degree will not change. However, from the long-term performance of stocks, the too high PE ratio of stocks with interest transfer on the first day of listing is actually an overdraw of its future performance, which results in poor long-term performance of stock price [4].

The author conducts tests respectively from the PE, discounts and one-year returns of IPO and puts forward the following hypothesis:

H1: The "Direct Investment + Sponsor" mode has prominently positive (negative) effects on the discount of new stocks.

H2: The "Direct Investment + Sponsor" mode has prominently positive (negative) effects on the long-term performance of stock price for companies to be listed after IPO.

\section{Research Design}

Considering that the cancellation policy for "Sponsor + Direct Investment" mode was issued in July 2011 and the latest policy was released on December 31, 2016, the author selects all IPO companies from January 1, 2012 to December 31, 2016 and deletes companies in the financial industry and some companies that intend to IPO with missing data and 996 companies that intend to IPO are totally collected. The data in this paper is mainly from the Choice database, whether participating in the direct investment business or not is manually ob- 
tained from the prospectus disclosed in the Micro Data website. Data processing is mainly completed with Excel software and the final statistics and regression results are obtained with Stata software.

The dependent variable in this paper mainly includes discount UNDERPRICE, IPO P/E ratio PE_RATIO and RETURN: 1) UNDERPRICE is the percentage gain of the listed company closing price on the first day against issue price, which is derived in Excel with the Choice function. 2) RETURN is the percentage gain of closing price one year after the listing/closing price on the first day, which is derived in Excel with the Choice function.

Selection of some other key control variables: 1) Underwriter's reputation UR_RP, use the logarithm of domestic securities trader annual IPO underwriting amount from 2012 to 2016 as the underwriter's reputation and alternative indicator; 2) the last year of reporting period, operating activity cash flow of each stock is taken as the performance variable of companies that intend to IPO; 3 ) the growth rate of net profit is taken as the growth variable of companies that intend to IPO; 4) the asset-liability ratio is taken as the performance variable of companies that intend to IPO.

According to the theoretical analysis and hypothesis and referring to the model of Zhang Yichun and Hong Tu (2012), the author tests the relationship between "Direct Investment + Sponsor" mode and discount of new shares. These following models are constructed:

$$
\begin{aligned}
\text { UNDERPRICE }_{\mathrm{i}}= & \alpha_{0}+\alpha_{1} \mathrm{UR}_{-} \text {DIRECT }_{\mathrm{i}}+\alpha_{2} \mathrm{UR}_{-} \mathrm{RP}_{\mathrm{i}}+\alpha_{3} \mathrm{OCF}_{\mathrm{i}}+\alpha_{4} \mathrm{PG}_{\mathrm{i}} \\
& +\alpha_{5} \mathrm{LEV}_{\mathrm{i}}+\alpha_{6} \mathrm{SIZE}_{\mathrm{i}}+\alpha_{7} \mathrm{SOE}_{\mathrm{i}}+\alpha_{8} \mathrm{VC}_{-} \mathrm{PE}_{\mathrm{i}} \\
& +\alpha_{9} \mathrm{IND}_{\mathrm{i}}+\alpha_{10} \mathrm{INDEX}_{\mathrm{i}}+\alpha_{11} \mathrm{YEAR}_{\mathrm{j}}
\end{aligned}
$$

To test the relationship between the "Direct Investment + Sponsor" mode and one-year returns, the author constructs the following model (Table 2):

$$
\begin{aligned}
\text { RETURN }_{\mathrm{i}}= & \beta_{0}+\beta_{1} \mathrm{UR}_{-} \mathrm{DIRECT}_{\mathrm{i}}+\beta_{2} \mathrm{UR}_{-} \mathrm{RP}_{\mathrm{i}}+\beta_{3} \mathrm{OCF}_{\mathrm{i}}+\beta_{4} \mathrm{PG}_{\mathrm{i}} \\
& +\beta_{5} \mathrm{LEV}_{\mathrm{i}}+\beta_{6} \mathrm{SIZE}_{\mathrm{i}}+\beta_{7} \mathrm{SOE}_{\mathrm{i}}+\beta_{8} \mathrm{VC}_{-} \mathrm{PE}_{\mathrm{i}} \\
& +\beta_{9} \mathrm{IND}_{\mathrm{i}}+\beta_{10} \mathrm{INDEX}_{-} \mathrm{YEAR}_{\mathrm{i}}
\end{aligned}
$$

\section{Empirical Results and Analysis}

\subsection{Descriptive Statistics}

The total number of samples is 996 and the descriptive statistics of each variable are shown in the following Table 3. Based on the "Direct Investment + Sponsor" mode and non-"Direct Investment + Sponsor" mode, samples are conducted the classification statistics in Table 3 . It can be seen from Table 3 that neither "Direct Investment + Sponsor" mode nor non-“Direct Investment + Sponsor" mode there are different degrees of premiums. Moreover, the premium level 6.07 under non-"Direct Investment + Sponsor" mode is higher than the premium level 5.09 under "Direct Investment + Sponsor" mode, to a certain extent which implies that as the scarce resources, companies that intend to IPO and be listed generally have relatively high premiums. The relatively low premium under the "Direct Investment + Sponsor" mode shows that in the stock issuance Chinese 
Table 2. Variable definition.

\begin{tabular}{|c|c|c|}
\hline Type & Variable Name & Variable Definition \\
\hline \multirow{2}{*}{$\begin{array}{l}\text { Dependent } \\
\text { variable }\end{array}$} & UNDERPRICE & $\begin{array}{l}\text { UNDERPRICE, the percentage gain of the listed company } \\
\text { closing price on the first day against issue price }\end{array}$ \\
\hline & RETURN & $\begin{array}{l}\text { RETURN, the percentage gain of closing price one year after } \\
\text { the listing against closing price on the first day }\end{array}$ \\
\hline \multirow[t]{6}{*}{$\begin{array}{l}\text { Explaining } \\
\text { variable }\end{array}$} & UR_DIRECT & $\begin{array}{c}\text { Dummy variable of direct investment and sponsor, when the } \\
\text { direct investment department of securities companies to } \\
\text { which the sponsor institution of issuer belongs holds shares } \\
\text { of issuer } t \text {, it is } 1 \text {, otherwise, it is } 0\end{array}$ \\
\hline & UR_RP & $\begin{array}{l}\text { Underwriter's reputation, it uses the logarithm of } \\
\text { domestic securities trader annual IPO underwriting } \\
\text { amount from } 2012 \text { to } 2017 \text { as the underwriter's } \\
\text { reputation and alternative indicator }\end{array}$ \\
\hline & OCF & $\begin{array}{l}\text { operating activity cash flow of each stock, operating activity } \\
\text { cash flow of each stock in the last year of reporting period }\end{array}$ \\
\hline & PG & $\begin{array}{l}\text { The growth rate of net profit, the growth rate of net } \\
\text { profit in the last year of issuer reporting period }\end{array}$ \\
\hline & LEV & $\begin{array}{l}\text { Asset-liability ratio, asset-liability ratio in } \\
\text { the last year of issuer reporting period }\end{array}$ \\
\hline & SIZE & $\begin{array}{l}\text { Asset size, Napierian logarithm of total assets } \\
\text { in the last year of issuer reporting period }\end{array}$ \\
\hline \multirow[t]{6}{*}{$\begin{array}{l}\text { Control } \\
\text { variable }\end{array}$} & SOE & $\begin{array}{l}\text { Dummy variable for ownership nature of the ultimate } \\
\text { controller, if ownership nature of the ultimate controller is } \\
\text { state-owned, find the value of } 1 \text {, otherwise, } 0\end{array}$ \\
\hline & VC_PE & $\begin{array}{c}\text { For issuer there are venture capital institutions and } \\
\text { private equity with shares, the dummy } \\
\text { variable finds the value of } 1 \text {, otherwise, } 0\end{array}$ \\
\hline & IND & $\begin{array}{l}\text { Industry dummy variable, if belonging to the primary } \\
\text { industry, find the value of } 1 \text {; if secondary industry, find the } \\
\text { value of } 2 \text {; if tertiary industry, find the value of } 3\end{array}$ \\
\hline & YEAR & Year DUM \\
\hline & INDEX & $\begin{array}{l}\text { The corresponding percentage gain of } \\
\text { index on the first day of listing }\end{array}$ \\
\hline & INDEX_YEAR & $\begin{array}{l}\text { The corresponding percentage gain of index } \\
\text { on the first day of listing in the same term }\end{array}$ \\
\hline
\end{tabular}

security investors tend to be more rational and require relatively lower premiums to make up for losses brought by the potential interest transfer. Meanwhile, the one-year return level of listed company's shares one year after the listing under non-Direct Investment + Sponsor" mode 16.91 is also higher than the one-year return level under the "Direct Investment + Sponsor" mode, which indicates during the stock issuance there may be interest transfer phenomenon so as to result in the consequence that the issuance price "overdraws" the future performance and "change" of performance. In addition, the author conducts the correlation test of model variables to indicate that there is no serious multicollinearity 
Table 3. The result of descriptive statistics.

\begin{tabular}{|c|c|c|c|c|c|c|c|c|}
\hline \multirow[b]{2}{*}{ Variable } & \multicolumn{2}{|c|}{ Mean } & \multicolumn{2}{|c|}{ Maximum } & \multicolumn{2}{|c|}{ Minimum } & \multicolumn{2}{|c|}{ Standard Deviation } \\
\hline & $\begin{array}{l}\text { Under "Direct } \\
\text { Investment + } \\
\text { Sponsor" } \\
\text { mode }\end{array}$ & $\begin{array}{c}\text { Under } \\
\text { non-“Direct } \\
\text { Investment + } \\
\text { Sponsor" } \\
\text { mode }\end{array}$ & $\begin{array}{l}\text { Under "Direct } \\
\text { Investment + } \\
\text { Sponsor" } \\
\text { mode }\end{array}$ & $\begin{array}{c}\text { Under } \\
\text { non-“Direct } \\
\text { Investment + } \\
\text { Sponsor" } \\
\text { mode }\end{array}$ & $\begin{array}{l}\text { Under "Direct } \\
\text { Investment + } \\
\text { Sponsor" } \\
\text { mode }\end{array}$ & $\begin{array}{c}\text { Under } \\
\text { non-“Direct } \\
\text { Investment + } \\
\text { Sponsor” } \\
\text { mode }\end{array}$ & $\begin{array}{c}\text { Under } \\
\text { "Direct } \\
\text { Investment + } \\
\text { Sponsor" } \\
\text { mode }\end{array}$ & $\begin{array}{c}\text { Under } \\
\text { non-“Direct } \\
\text { Investment+ } \\
\text { Sponsor” } \\
\text { mode }\end{array}$ \\
\hline UNDERPRICE & 5.0860 & 6.0657 & 23.7600 & 39.0100 & -2.6500 & -6.9300 & 4.4064 & 4.1520 \\
\hline RETURN & 13.2009 & 16.9053 & 184.94 & 227.5500 & -12.8200 & -31.6900 & 25.2716 & 21.7618 \\
\hline UR_RP & 13.3153 & 12.6804 & 14.4430 & 14.4430 & 10.0392 & 9.5324 & 0.9865 & 1.1480 \\
\hline OCF & 0.7541 & 0.9520 & 7.5847 & 22.5427 & -3.0400 & -2.2500 & 1.1797 & 1.2816 \\
\hline PG & 0.2968 & 0.2374 & 2.4546 & 8.5856 & -0.3579 & -0.7366 & 0.4730 & 0.5465 \\
\hline LEV & 0.4126 & 0.4150 & 0.9313 & 0.9820 & 0.0623 & 0.0465 & 0.1790 & 0.1755 \\
\hline SIZE & 20.6024 & 20.5622 & 25.7737 & 27.8028 & 18.9967 & 18.7756 & 1.0446 & 1.1388 \\
\hline SOE & 0.0136 & 0.0397 & 1 & 1 & 0 & 0 & 0.1170 & 0.1953 \\
\hline VC_PE & 0.5616 & 0.6374 & 1 & 1 & 0 & 0 & 0.4996 & 0.4809 \\
\hline IND & 2.2328 & 2.2259 & 3 & 3 & 2 & 1 & 0.4255 & 0.4357 \\
\hline INDEX & 0.0015 & 0.0003 & 0.0552 & 0.0552 & -0.0161 & -0.0739 & 0.0109 & 0.0136 \\
\hline INDEX_YEAR & -0.0029 & $2.93 e-06$ & 0.0475 & 0.0552 & -0.0642 & -0.0762 & 0.0206 & 0.0171 \\
\hline
\end{tabular}

among explanatory variables.

\subsection{Multivariate Regression Analysis}

The following Table 4 shows the regression results of dependent variable UNDERPRICE. In Model 1, it only uses UNDERPRICE to regress the dummy variable UR_DIRECT that stands for the "Direct Investment + Sponsor" mode and obtains the coefficient of UR_DIRECT is -1.0373 , which is significant at the level of 5\%. As adding the control variable, the coefficient of UR_DIRECT turns to -0.6238 and the absolute value of $t$ is less than 1.64 , which indicates that it has no significance. Therefore, the hypothesis 1 that "Direct Investment + Sponsor" mode has significant impacts on the discount of new stocks is rejected. In addition, the regression coefficient of variable SOE that represents whether the enterprise property is state-owned or not is significantly negative, which indicates that state-owned enterprises are facing higher discount prices on the first day of listing. The variable UR_RP that represents the reputation of underwriters is significantly positive, which indicates that the reputation of sponsor securities traders will have a promoting effect on the stock price performance of companies that intend to IPO on the first day of listing. The variables OCF and PG that represent performance and growth level have significantly positive impacts on premiums on the first day of listing, which is in line with common sense. Variables LEV and SIZE that represent leverage level and enterprise scale have significantly negative impacts on premiums on the first day of listing.

Based on examining impacts of "Direct Investment + Sponsor" mode on the 
Table 4. The regression results of dependent variables UNDERPRICE.

\begin{tabular}{|c|c|c|}
\hline UNDERPRICE & MODEL1 & MODEL2 \\
\hline UR_DIRECT & $\begin{array}{c}-1.0373 \\
(-2.06)^{\star *}\end{array}$ & $\begin{array}{c}-0.6238 \\
(-1.3400)\end{array}$ \\
\hline UR_RP & & $\begin{array}{c}0.3387^{\star * *} \\
(3.1300)\end{array}$ \\
\hline OCF & & $\begin{array}{l}1.0474^{* * *} \\
(10.6300)\end{array}$ \\
\hline PG & & $\begin{array}{c}1.4435^{\star * *} \\
(6.5600)\end{array}$ \\
\hline LEV & & $\begin{array}{c}-2.9233^{* * *} \\
(-3.4100)\end{array}$ \\
\hline SIZE & & $\begin{array}{c}-0.5460^{\star * *} \\
(-3.6300)\end{array}$ \\
\hline SOE & & $\begin{array}{l}-1.4020^{\star \star} \\
(-2.1700)\end{array}$ \\
\hline VC_PE & & $\begin{array}{c}0.0531 \\
(0.1800)\end{array}$ \\
\hline INDEX & & $\begin{array}{c}-7.4966 \\
(-0.8500)\end{array}$ \\
\hline IND2 & & $\begin{array}{c}1.4962 \\
(1.0600)\end{array}$ \\
\hline IND3 & & $\begin{array}{c}1.7523 \\
(1.2300)\end{array}$ \\
\hline YEAR2014 & & $\begin{array}{c}5.0893^{* * *} \\
(9.7300)\end{array}$ \\
\hline YEAR2015 & & $\begin{array}{c}3.2874^{\star * *} \\
(6.5500)\end{array}$ \\
\hline YEAR2016 & & $\begin{array}{c}2.8242^{\star * *} \\
(5.4300)\end{array}$ \\
\hline Ajusted R-squared & 0.0032 & 0.2315 \\
\hline F-statistic & 4.2400 & 20.6200 \\
\hline
\end{tabular}

Notes: what given in brackets is the test value of $\mathrm{t}$ and ${ }^{*},{ }^{* *}, * *$ respectively means the significance of confidence level in $10 \%, 5 \%$ and $1 \%$.

stock price performance on the first day of listing, the author conducts multiple regression analysis on the relationship between one-year return RETURN and "Direct Investment + Sponsor" mode and the results are shown in the following Table 5. The regression coefficient of variable UR_DIRECT that stands for " $\mathrm{Di}$ rect Investment + Sponsor" mode is -6.2134 but is not statistically significant, which indicates that the long-term performance of listed companies under the "Direct Investment + Sponsor" mode is no different from that of non-listed companies, based on which hypothesis 2 is rejected. In addition, the variable UR_RP that represents the reputation of underwriters is significantly negative, which indicates that the better the underwriter's reputation, the worse one-year 
Table 5. The regression results of dependent variables RETURN.

\begin{tabular}{|c|c|c|}
\hline RETURN & MODEL1 & MODEL2 \\
\hline UR_DIRECT & $\begin{array}{l}-3.8649 \\
(-1.44)\end{array}$ & $\begin{array}{c}-6.2134 \\
(-1.4600)\end{array}$ \\
\hline UR_RP & & $\begin{array}{l}-2.2025^{\star *} \\
(-2.2000)\end{array}$ \\
\hline OCF & & $\begin{array}{c}1.0304 \\
(1.0500)\end{array}$ \\
\hline PG & & $\begin{array}{c}-6.3203^{\star * *} \\
(-2.6700)\end{array}$ \\
\hline LEV & & $\begin{array}{c}-5.2067 \\
(-0.6400)\end{array}$ \\
\hline SIZE & & $\begin{array}{l}-3.2237^{\star *} \\
(-2.2700)\end{array}$ \\
\hline SOE & & $\begin{array}{c}-7.1965 \\
(-0.9900)\end{array}$ \\
\hline VC_PE & & $\begin{array}{l}4.9172^{\star *} \\
(2.0700)\end{array}$ \\
\hline INDEX_YEAR & & $\begin{array}{c}-118.6383^{\star *} \\
(-1.80)\end{array}$ \\
\hline IND2 & & $\begin{array}{c}2.7848 \\
(0.3100)\end{array}$ \\
\hline IND3 & & $\begin{array}{l}13.4809 \\
(1.4800)\end{array}$ \\
\hline Ajusted R-squared & 0.0011 & 0.1225 \\
\hline F-statistic & 2.0800 & 5.5300 \\
\hline
\end{tabular}

Notes: what given in brackets is the test value of $\mathrm{t}$ and ${ }^{*},{ }^{* *},{ }^{* *}$ respectively means the significance of confidence level in $10 \%, 5 \%$ and $1 \%$.

stock performance, which is not in line with the common sense and there may be behaviors that underwriters deliberately raise the issue prices so as to raise the performance. In the listing of companies that intend to IPO, shareholding of risk capital and private-equity firms has significantly positive impacts on long-term performance of listed companies, which indicates that shareholding of risk capital and private-equity firms play the role of screening performance.

Based on the above analysis, there is no significant difference between listed companies in the "Direct Investment + Sponsor" mode and listed companies in the non-"Direct Investment + Sponsor" mode on aspects of the first-day stock price performance and the one-year return level. Moreover, these two levels are both used to measure the situation of interest transfer. Therefore, it can be obtained that the existing "Direct Investment + Sponsor" mode will not cause the situation of interest transfer between internal direct investment departments and investment bank departments within securities traders. Meanwhile, it indicates that the firewall mechanism in securities traders is valid and the effective isolation in business is achieved. 


\subsection{Solidity Test}

Taking into account that companies that intend to IPO under the "Direct Investment + Sponsor" mode are listed on the Main Board of Shanghai Stock Exchange, Growth Enterprises Market of Shenzhen Stock Exchange and Small and Medium-sized Enterprises Board of Shenzhen Stock Exchange, in order to test the robustness of results, the author respectively narrows the sample range to the Main Board of Shanghai Stock Exchange (Number of samples, 428), Growth Enterprises Market of Shenzhen Stock Exchange (Number of samples, 364) and Small and Medium-sized Enterprises Board of Shenzhen Stock Exchange (Number of samples, 215) and conducts the regression test again, the results are shown in Table 6 and Table 7 below. It can be seen from the results in the

Table 6. The results of solidity test based on dependent variable UNDERPRICE.

\begin{tabular}{|c|c|c|c|c|c|c|}
\hline \multirow{2}{*}{ UNDERPRICE } & \multicolumn{2}{|c|}{ Main-board Market } & \multicolumn{2}{|c|}{ Second-board Market } & \multicolumn{2}{|c|}{ SME-board Market } \\
\hline & MODEL1 & MODEL2 & MODEL1 & MODEL2 & MODEL1 & MODEL2 \\
\hline UR_DIRECT & $\begin{array}{c}-0.6772 \\
(-1.0700)\end{array}$ & $\begin{array}{c}-0.7158 \\
(-1.1800)\end{array}$ & $\begin{array}{c}-1.1804 \\
(-1.2200)\end{array}$ & $\begin{array}{c}-0.6944 \\
(-0.9100)\end{array}$ & $\begin{array}{c}-1.6812 \\
(-1.6100)\end{array}$ & $\begin{array}{c}-0.3365 \\
(-0.3000)\end{array}$ \\
\hline UR_RP & & $\begin{array}{c}0.4413 \\
(2.8500)\end{array}$ & & $\begin{array}{l}0.3486^{* *} \\
(1.9700)\end{array}$ & & $\begin{array}{c}0.2437 \\
(1.0900)\end{array}$ \\
\hline OCF & & $\begin{array}{c}0.6735^{* * *} \\
(6.5800)\end{array}$ & & $\begin{array}{l}3.0459^{* * *} \\
(11.7000)\end{array}$ & & $\begin{array}{l}0.5691^{* *} \\
(2.2300)\end{array}$ \\
\hline PG & & $\begin{array}{l}0.8310^{* *} \\
(3.2000)\end{array}$ & & $\begin{array}{c}1.7015^{* * *} \\
(3.9100)\end{array}$ & & $\begin{array}{c}1.7387^{* * *} \\
(3.4600)\end{array}$ \\
\hline LEV & & $\begin{array}{l}-3.2117^{* *} \\
(-3.0300)\end{array}$ & & $\begin{array}{c}-1.5950 \\
(-0.9900)\end{array}$ & & $\begin{array}{c}-1.9467 \\
(-1.0500)\end{array}$ \\
\hline SIZE & & $\begin{array}{c}-0.3965 \\
(-2.1900)\end{array}$ & & $\begin{array}{c}-0.1486 \\
(-0.3400)\end{array}$ & & $\begin{array}{c}0.0520 \\
(0.1400)\end{array}$ \\
\hline SOE & & $\begin{array}{l}-1.4679^{\star *} \\
(-2.2500)\end{array}$ & & $\begin{array}{l}-3.9891^{\star *} \\
(-2.2900)\end{array}$ & & $\begin{array}{c}0.8247 \\
(0.4600)\end{array}$ \\
\hline VC_PE & & $\begin{array}{c}0.0131 \\
(0.0300)\end{array}$ & & $\begin{array}{c}0.5465 \\
(0.9600)\end{array}$ & & $\begin{array}{c}-0.2169 \\
(-0.3500)\end{array}$ \\
\hline INDEX & & $\begin{array}{c}-2.8657 \\
(-0.2400)\end{array}$ & & $\begin{array}{c}-9.2730 \\
(-0.6200)\end{array}$ & & $\begin{array}{l}-20.0257 \\
(-1.1100)\end{array}$ \\
\hline IND2 & & & & $\begin{array}{c}1.8583 \\
(0.6700)\end{array}$ & & $\begin{array}{c}1.9571 \\
(1.1800)\end{array}$ \\
\hline IND3 & & $\begin{array}{c}0.4285 \\
(1.1300)\end{array}$ & & $\begin{array}{c}2.5404 \\
(0.9100)\end{array}$ & & $\begin{array}{c}1.6884 \\
(0.9600)\end{array}$ \\
\hline & & $\begin{array}{c}3.0011^{* * *} \\
(3.2200)\end{array}$ & & $\begin{array}{c}7.0146^{* * *} \\
(8.4800)\end{array}$ & & $\begin{array}{c}4.3892^{* * *} \\
(4.8200)\end{array}$ \\
\hline YEAR2015 & & $\begin{array}{l}2.1678^{\star *} \\
(2.4400)\end{array}$ & & $\begin{array}{c}2.5637^{* * *} \\
(3.0300)\end{array}$ & & $\begin{array}{c}4.1170^{* * *} \\
(4.4900)\end{array}$ \\
\hline YEAR2016 & & $\begin{array}{l}1.6592^{\star *} \\
(2.5500)\end{array}$ & & $\begin{array}{c}2.7394^{* * *} \\
(3.1400)\end{array}$ & & $\begin{array}{c}3.7613^{* * *} \\
(3.9100)\end{array}$ \\
\hline $\begin{array}{c}\text { Adjusted } \\
\text { R-squared }\end{array}$ & 0.0003 & 0.1873 & 0.0013 & 0.4105 & 0.0074 & 0.1854 \\
\hline F-statistic & 1.1400 & 7.6700 & 1.5000 & 17.8500 & 2.5900 & 4.1400 \\
\hline
\end{tabular}

Notes: what given in brackets is the test value of $\mathrm{t}$ and ${ }^{*},{ }^{* *},{ }^{* *}$ respectively means the significance of confidence level in $10 \%, 5 \%$ and $1 \%$. 
Table 7. The results of solidity test based on dependent variable RETURN.

\begin{tabular}{|c|c|c|c|c|c|c|}
\hline RETURN & MODEL1 & MODEL2 & MODEL1 & MODEL2 & MODEL1 & MODEL2 \\
\hline UR_DIRECT & $\begin{array}{c}0.4768 \\
(0.1400)\end{array}$ & $\begin{array}{l}-8.7766^{*} \\
(-1.6700)\end{array}$ & $\begin{array}{l}-7.1106 \\
(-1.3800)\end{array}$ & $\begin{array}{c}0.7995 \\
(0.1000)\end{array}$ & $\begin{array}{l}-7.2899 \\
(-1.3500)\end{array}$ & $\begin{array}{c}-9.4274 \\
(-1.1100)\end{array}$ \\
\hline UR_RP & & $\begin{array}{c}-1.1605 \\
(-0.8800)\end{array}$ & & $\begin{array}{l}-2.2524 \\
(-1.3200)\end{array}$ & & $\begin{array}{c}-0.2284 \\
(-0.1000)\end{array}$ \\
\hline OCF & & $\begin{array}{c}1.0443 \\
(1.1900)\end{array}$ & & $\begin{array}{c}1.2288 \\
(0.3900)\end{array}$ & & $\begin{array}{c}3.5574 \\
(1.3200)\end{array}$ \\
\hline PG & & $\begin{array}{c}-5.2333 \\
(-1.2900)\end{array}$ & & $\begin{array}{c}-14.0550^{\star * *} \\
(-3.1500)\end{array}$ & & $\begin{array}{c}-1.2913 \\
(-0.3100)\end{array}$ \\
\hline LEV & & $\begin{array}{c}3.2195 \\
(0.3600)\end{array}$ & & $\begin{array}{l}-25.5271 \\
(-1.5200)\end{array}$ & & $\begin{array}{l}11.7061 \\
(0.6700)\end{array}$ \\
\hline SIZE & & $\begin{array}{l}-4.7521^{\star *} \\
(-3.0000)\end{array}$ & & $\begin{array}{c}0.0508 \\
(0.0100)\end{array}$ & & $\begin{array}{c}-3.6379 \\
(-1.0000)\end{array}$ \\
\hline SOE & & $\begin{array}{l}-3.1208 \\
(-0.4900)\end{array}$ & & $\begin{array}{l}-36.0828 \\
(-1.4800)\end{array}$ & & $\begin{array}{c}-9.4709 \\
(-0.5500)\end{array}$ \\
\hline VC_PE & & $\begin{array}{c}0.3225 \\
(0.1200)\end{array}$ & & $\begin{array}{c}10.0605^{\star *} \\
(2.2400)\end{array}$ & & $\begin{array}{l}9.9431^{*} \\
(1.9000)\end{array}$ \\
\hline INDEX_YEAR & & $\begin{array}{c}-36.2468 \\
(-0.49)\end{array}$ & & $\begin{array}{c}-388.2704^{* * *} \\
(-3.1100)\end{array}$ & & $\begin{array}{l}126.4593 \\
(0.8300)\end{array}$ \\
\hline IND2 & & & & $\begin{array}{c}9.8787 \\
(0.5600)\end{array}$ & & $\begin{array}{c}1.2184 \\
(0.1000)\end{array}$ \\
\hline IND3 & & $\begin{array}{c}2.9314 \\
(0.9200)\end{array}$ & & $\begin{array}{l}17.5208 \\
(0.9800)\end{array}$ & & $\begin{array}{c}32.2834^{* *} \\
(2.4900)\end{array}$ \\
\hline $\begin{array}{l}\text { Adjusted } \\
\text { R-squared }\end{array}$ & -0.0023 & 0.1259 & 0.0024 & 0.1814 & 0.0039 & 0.1953 \\
\hline F-statistic & 0.0200 & 2.8400 & 1.9100 & 3.8200 & 1.8300 & 2.9200 \\
\hline
\end{tabular}

Notes: what given in brackets is the test value of $\mathrm{t}$ and ${ }^{*},{ }^{* *},{ }^{* *}$ respectively means the significance of confidence level in $10 \%, 5 \%$ and $1 \%$.

Table 6 that the "Direct Investment + Sponsor" mode has no significant effect on the discount of new stocks and one-year returns after the listing of companies that intend to IPO and the previous results are solid.

\section{Conclusions and Recommendations}

The direct investment business of securities traders plays a unique role in perfecting the market launch mechanism, supporting middle and small-sized enterprises for financing and listing as well as promoting the vigorous development of PE market. Under the premise that the firewall mechanism among departments of securities traders works well, the "Direct Investment + Sponsor" mode, as the business that broadens the revenue channels and profit models of securities traders, is of great significance for improving that securities traders take brokerage as the single income source and broadening business scopes.

The above research shows that there is no significant difference between companies that intend to IPO under the "Direct Investment + Sponsor" mode 
and companies that intend to IPO under the non- "Direct Investment + Sponsor" mode in the discount of new stocks and one-year returns. The result shows that the firewall mechanism between the direct investment department and the investment banking department of Chinese securities traders is in good condition, verifies the rationality of not abolishing "Direct Investment + Sponsor" mode in Guidelines for Direct Investment Business of Securities Companies introduced by China Securities Regulatory Commission in July 2011 and powerfully refutes the market's long-lasting query that China Securities Regulatory Commission retains "Direct Investment + Sponsor" mode. Meanwhile, it provides evidence for the existence compliance of "Direct Investment + Sponsor" mode with financial innovation made by securities traders on the occasion of introducing new policies such as Management Standards for Private Equity Subsidiaries of Securities Companies and Management Standard for Alternative Investment Subsidiaries of Securities Companies.

Management Standards for Private Equity Subsidiaries of Securities Companies and Management Standard for Alternative Investment Subsidiaries of Securities Companies introduced in December 2016 are the re-promotion for supervision and regulation of "Direct Investment + Sponsor" mode, which puts forward new requirements for securities traders to develop the "Direct Investment + Sponsor" mode in the future: 1) In principle, there should not be more than one private equity subsidiary of securities companies; 2) Private equity subsidiaries of securities companies should be established by their wholly-owned funds; 3) The investment amount in a single fund cannot exceed $20 \%$ total amount of this fund. Actually, these provisions make further division of direct investment institutions in securities traders from the parent company so as to avoid the interest transfer. Under such guidance of more stringent supervision and regulation, if such advantages of securities trader direct investment institutions as strong risk control system and tremendous capital security are developed, the "Direct Investment + Sponsor" mode will be conducive to the rational, compliant and effective operation and development of capital markets.

Although this paper judges whether there is the interest transfer in the "Direct Investment + Sponsor" mode and demonstrates the existence rationality of " $\mathrm{Di}$ rect Investment + Sponsor" mode. However, the specific process is still a reasonable guess for that the public information of interest transfer process is still not found. In the future, it needs the further study to combine with the regulatory policies newly introduced in December 2016 and find out the interest transfer points under new policies as well as eliminate potential problems.

\section{References}

[1] Zhang, Y.C. and Hong, T. (2012) Whether Direct Investment Sponsor Mode Aggravates Conflicts of Interest. Investment Research, Issue 7.

[2] Kroszner, R.S. and Rajan, R.G. (1994) Is the Glass-Steagall Act Justified? A Study of the U.S. Experience with Universal Banking before 1933. The American Economic Review, 84. 
[3] Gompers, P. and Lerner, J. (1998) Conflict of Interest in the Issuance of Public Securities: Evidence from Venture Capital. Working Paper.

[4] Hamao, Y., Packer, F. and Ritter, J.R. (2000) Institutional Affiliation and the Role of Venture Capital Evidence from Initial Public Offerings in Japan. Pacific-Basin Finance Journal, 8, 529-558. https://doi.org/10.1016/S0927-538X(00)00026-3 